\title{
Analisis Perbedaan Perbankan Syariah Dengan Perbankan Konvensional
}

\author{
Nanang Sobarna \\ Prodi Ekonomi Syariah Institut Manajemen Koperasi Indonesia \\ nanangsobarna85@gmail.com
}

\begin{abstract}
ABSTRAK
Perbankan syariah merupakan lembaga keuangan yang memiliki peran sangat penting dalam memajukan perekonomian Indonesia serta sebagai jawaban atas kebutuhan masyarakat untuk menggunakan sistem perbankan berdasarkan prinsip syariah. Namun terkadang banyak persepsi yang menganggap bahwa perbankan syariah sama saja dengan perbankan konvensional. Perbankan syariah memiliki perbedaan mendasar dengan perbankan konvensional yaitu menyangkut aspek legal, struktur organisasi, kegiatan usaha yang dibiayai dan lingkungan kerja. Kegiatan operasional Perbankan syariah berdasarkan prinsip syariah, yaitu prinsip bagi hasil, prinsip jual beli dan sewa dengan menjalankan usaha melalui akad mudharabah, musyarokah, murabbahah dan ijaroh. Sedangkan perbankan konvensional memberikan jasa dalam lalulintas pembayaran dengan prinsip penetapan bunga baik untuk produk simpanan maupun pinjaman (kredit) serta menerapkan berbagai biaya dalam bentuk nominal dan persentase tertentu.
\end{abstract}

Kata Kunci: perbankan syariah, prinsip syariah, perbankan konvensional.

\begin{abstract}
Islamic banking is a financial institution that has a very important role in advancing the Indonesian economy as well as responding to the community's need to use a banking system based on sharia principles. However, sometimes there are many perceptions that Islamic banking is the same as conventional banking. Islamic banking has fundamental differences with conventional banking, namely regarding legal aspects, organizational structure, financed business activities and work environment. Sharia banking operations are based on sharia principles, namely the principle of profit sharing, the principle of buying and selling and leasing by running a business through mudharabah, musyarokah, murabbahah and ijaroh contracts. While conventional banking provides services in payment traffic with the principle of setting interest for both deposit and loan products (credit) and applying various fees in the form of nominal and certain percentages.
\end{abstract}

Keywords: Islamic banking, sharia principles, conventional banking.

\section{PENDAHULUAN}

Bank merupakan salah satu lembaga keuangan yang mempunyai peranan penting di dalam perekonomian negara sebagai lembaga keuangan. Pasal 1 ayat (2) UU No. 10 Tahun 1998 tentang perubahan UU No. 7 Tahun 1992 tentang perbankan, bahwa bank 
adalah badan usaha yang menghimpun dana dari masyarakat dalam bentuk simpanan dan menyalurkannya kepada masyarakat dalam bentuk kredit dan atau bentuk-bentuk lain dalam rangka meningkatkan taraf hidup rakyat banyak. Jenis bank di Indonesia dibedakan menjadi dua jenis bank, yang dibedakan berdasarkan pembayaran bunga atau bagi hasil usaha:

1. Bank yang melakukan usaha secara konvensional.

2. Bank yang melakukan usaha secara syariah.

Bank Konvensional dan Bank Syariah dalam beberapa hal memiliki persamaan, terutama dalam sisi teknis penerimaan uang, mekanisme transfer, teknologi komputer yang digunakan, syarat-syarat umum memperoleh pembiayaan seperti KTP, NPWP, proposal, laporan keuangan, dan sebagainya. Perbedaan mendasar diantara keduanya menurut yaitu menyangkut aspek legal, struktur organisasi, usaha yang dibiayai dan lingkungan kerja (Muhammad Syafi'I Antonio, 2009: 29).

Perkembangan industri keuangan syariah secara informal telah dimulai sebelum dikeluarkannya kerangka hukum formal sebagai landasan operasional perbankan di Indonesia. Beberapa badan usaha pembiayaan non-bank telah didirikan sebelum tahun 1992 yang telah menerapkan konsep bagi hasil dalam kegiatan operasionalnya. Hal tersebut menunjukkan kebutuhan masyarakat akan hadirnya institusi-institusi keuangan yang dapat memberikan jasa keuangan yang sesuai dengan syariah.

Kebutuhan masyarakat tersebut telah terjawab dengan terwujudnya sistem perbankan yang sesuai syariah. Pemerintah telah memasukkan kemungkinan tersebut dalam undang-undang yang baru. Undang-Undang No.7 Tahun 1992 tentang Perbankan secara implisit telah membuka peluang kegiatan usaha perbankan yang memiliki dasar operasional bagi hasil yang secara rinci dijabarkan dalam Peraturan Pemerintah No. 72 Tahun 1992 tentang Bank Berdasarkan Prinsip Bagi Hasil. Ketentuan tersebut telah dijadikan sebagai dasar hukum beroperasinya Bank Syariah di Indonesia.

Periode 1992 sampai 1998, hanya terdapat satu Bank Umum Syariah dan 78 Bank Perkreditan Rakyat Syariah (BPRS) yang telah beroperasi. Tahun 1998 muncul UU No. 10 tahun 1998 tentang perubahan UU No 7 Tahun 1992 tentang perbankan. Perubahan UU tersebut menimbulkan beberapa perubahan yang memberikan peluang yang lebih besar bagi pengembangan Bank Syariah. Undang-undang tersebut telah mengatur secara rinci landasan hukum serta jenis-jenis usaha yang dapat dioperasikan dan diimplementasikan oleh Bank Syariah. Undang-undang tersebut juga memberikan arahan bagi bank-Bank Konvensional untuk membuka cabang syariah atau bahkan mengkonversi diri secara total menjadi Bank Syariah. Pada akhirnya pemerintah menerbitkan Undang-Undang No.21 Tahun 2008 tentang Perbankan Syariah, sehingga perbankan syariah memiliki undang-undang secara independen yang akan memperkuat keberadaan perbankan syariah di Indonesia.

Perkembangan bank umum syariah dan Bank Konvensional yang membuka cabang syariah juga didukung dengan tetap bertahannya Bank Syariah pada saat perbankan nasional mengalami krisis cukup parah pada tahun 1998. Sistem bagi hasil perbankan syariah yang diterapkan dalam produk-produk Bank Muamalat menyebabkan bank tersebut relatif mempertahankan kinerjanya dan tidak hanyut oleh tingkat suku bunga simpanan yang melonjak sehingga beban operasional lebih rendah dari Bank Konvensional (Muhammad: 2005). 
Hal mendasar yang membedakan antara lembaga keuangan konvensional dengan syariah adalah terletak pada pengembalian dan pembagian keuntungan yang diberikan oleh nasabah kepada lembaga keuangan dan/atau yang diberikan oleh lembaga keuangan kepada nasabah (Muhammad: 2005). Kegiatan operasional Bank Syariah menggunakan prinsip bagi hasil (profit and loss sharing). Bank Syariah tidak menggunakan bunga sebagai alat untuk memperoleh pendapatan maupun membebankan bunga atas penggunaan dana dan pinjaman karena bunga merupakan riba yang diharamkan.

\section{PEMBAHASAN}

\section{A. Hakikat, Latar Belakang dan Karakter Bank Syariah}

Pertumbuhan ekonomi yang tinggi tanpa diikuti dengan distribusi yang merata, akan menyebabkan ketimpangan sosial. Di satu pihak terdapat segelintir orang menikmati sebagian besar kekayaan, sementara disisi lain berhimpun mayoritas masyarakat yang sekedar memperebutkan sepiring kecil rezeki. Akibatnya terjadilah keadaan dimana sejumlah kecil orang makin bertambah kaya karena menguasai barang dan modal, sedangkan disaat yang sama banyak masyarakat yang hidup dibawah garis kemiskinan. Hal ini semakin diperburuk lagi dengan adanya penindasan dan pemerasan oleh yang kuat terhadap yang lemah, atau oleh si kaya terhadap si miskin. Keadaan yang seperti ini tidak terjadi dengan sendirinya, melainkan sengaja diciptakan, sehingga menutup peluang golongan dhu'afa untuk memperbaiki kondisi sosial ekonominya. Sekeras apapun ia bekerja atau sepintar apapun kemampuan yang dimilikinya, ia tetap menjadi pelengkap penderita bagi golongan atas.

Sebaliknya, pemerataan tanpa pertumbuhan juga tidaklah tepat, karena akan menghambat dinamika ekonomi dan menyebabkan pembagian kemiskinan. Semakin besar faktor pembaginya ( sementara jumlah yang dibagi tetap), akan memperbesar pembagian kemiskinan. Pendapatan seorang pegawai mungkin cukup untuk menghidupi suatu keluarga kecil. Namun bila pendapatan tersebut digunakan untuk menghidupi keluarga yang besar, tentu saja tidak mencukupi.

Untuk menciptakan keselarasan antara pertumbuhan dan pemerataan itu, diperlukan lembaga yang mengendalikan dan mengatur dinamika ekonomi dalam hal ini perputaran uang dan barang. Fungsi itu sekarang dikenal dengan nama bank. Bank dalam bentuk dasarnya sesungguhnya banyak membawa manfaat, karena disitu bertemu para pemilik, pengguna, dan pengelola modal. Dari sana terjadi proses perputaran uang dan kekayaan dari kelompok kaya kepada mereka yang memerlukan.

Dari sudut ini, bank memiliki fungsi menebarkan keadilan dan pemerataan. Selain itu, bank juga berperan memperlancar laju perekonomian. Berbagai transaksi baik berskala lokal maupun internasional-membutuhkan jasa perbankan. Transfer dana, rekening giro, penerbitan L/C , deposit box, tukar menukar valuta asing dan berbagai jenis pelayanan jasa lainnya hanya ada di bank. Disamping itu bank adalah tempat yang aman untuk menitipkan dana. Namun fakta dalam kenyataan kini, yang pongah berkibar adalah bankbank yang sedang menganut sistem ribawi. Sistem ini sejak semula diciptakan sebagai alat untuk melakukan penindasan kepada kaum tidak berpunya dan melestarikan jurang pemisah antara pemilik modal dengan pembutuh modal.

Diberlakukannya sistem ribawi atas seluruh transaksi yang dilakukan oleh dunia perbankan, membuat seluruh peran positifnya bergeser dan berbalik menghancurkan 
sendi-sendi kehidupan umat. Bank sekarang justru berperan sebagai lembaga penindasan yang lemah dan penopang yang kuat. Disisi lain kita melihat dari mana uang datang dan kepada siapa dana itu disalurkan. Bukan rahasia lagi, bank hanya menyalurkan kredit kepada golongan tertentu yang mampu menyerahkan agunan. Sementara kaum lemah amat sulit memperoleh kredit, bahkan nyaris mustahil. Selain tidak memiliki agunan, juga skala bisnis yang kecil membuat bank tidak tertarik untuk membantu. Dengan kata lain bank menganggap orang kecil tidak bankable. Namun celakanya dana yang disedot para konglomerat untuk mempertajam cengkraman gurita bisnisnya ( pinjaman dari bank), tidak sedikit yang datang dari kaum lemah. Dengan berbagai iming-iming dan hadiah, mereka ini (kaum lemah) dirayu agar menyimpan uangnya di bank. Secara makro, jeratan bank ribawi juga menimpa banyak dunia ketiga. Yahudi, melalui sistem ribanya, membelit negara-negara dunia ketiga dengan utang yang tak kepalang jumlahnya. Sampai tahun 1989 saja, diperkirakan utang negara-negara Dunia (termasuk didalamnya negara-negara Islam) mencapai 1,4 triliun dollar Amerika. Maka masuk diakal jika perekonomian di kawasan ini (dunia ketiga) menjadi morat-marit, bak lingkaran setan. Oleh karena itu harus ada alternatif lain yang mampu membuat bank menjalankan peranannya bagi kesejahteraan umat.

Dalam transaksi ribawi yang ada hanyalah resiko satu pihak. Hanya pihak peminjam yang menanggung resiko, sementara pemilik modal selalu mendapat keuntungan. Ini adalah suatu kezaliman total yang nyata. Hal seperti ini tentulah tidak akan ditemui pada lembaga keuangan non bunga atau dengan kata lain Bank Syariah. Istilah Bank Syariah sebenarnya baru berkembang di masa-masa sekarang ini. Sedangkan pada khazanah fiqh dan praktek ekonomi di masa rasul dan khilafah islamiyah, istilah Bank Syariah lebih dikenal dengan nama baitul maal atau baitul tawil.

Isu tentang Bank Syariah yang sejak lama (baik secara terbuka atau samar-samar sering digunakan) nampak makin menemukan momentumnya. Di Indonesia, sebelum berdirinya bank Muamalat, isu tersebut ramai dibicarakan berbagai kalangan, baik dalam skala besar maupun kecil. Dan isu tersebut pun berubah menjadi kenyataan seiring dengan berdirinya bank Muamalat di Indonesia. Berdirinya bank Muamalat ini telah lama dinantikan dan diharapkan oleh masyarakat Indonesia, khususnya umat Islam yang menjadi mayoritas di negeri ini. Kekecewaan masyarakat, khususnya dari golongan menengah kebawah, kepada bank-bank konvensional yang kian merajalela dengan sistem ribawinya, ditambah lagi dengan adanya resesi dunia, membuat masyarakat mencari alternatif lain yang lebih manusiawi dan adil. Apalagi Bank Syariah berhasil membuktikan dirinya sebagai lembaga keuangan yang sukses dari segi komersial dan moral. Secara komersial, Bank Syariah tersebut menghasilkan keuntungan berlimpah. Disisi lain ia tetap mampu memerankan dirinya lembaga keuangan dan ekonomi yang adil dan manusiawi yang mencakup segala kalangan masyarakat. Berbeda dengan bankbank konvensional yang pada hakekatnya tak lebih dari perpanjangan tangan kaum elite ekonomi dan konglomerat.

Dalam Islam, masalah ekonomi bukanlah masalah yang berdiri sendiri. Seluruhnya terkait dengan esensi ajaran Islam, yaitu Laa Illaha Illallah. Artinya prinsip dasar ekonomi islam memandang harta milik Allah SWT. Manusia hanyalah penerima amanah, yang harus dipertanggungjawabkan di hari akhir kelak. Karena itu , seluruh aturan ekonomi Islam, termasuk Bank Syariah, selalu berorientasi kepada bagaimana keridhoan Allah dapat kita peroleh. Hakekat sistem Islam yang lain adalah keintegralannya. Ekonomi , Politik , Sosial, Budaya dan bagian kehidupan yang lain, 
menyatu dalam satu sistem. Artinya penegakan sistem Islam selalu mensyaratkan adanya keseluruhan dalam pelaksanaanya. Jika tidak, maka bisa jadi malah akan menimbulkan masalah baru yang tidak jarang jauh lebih kompleks dari sebelumnya. Rahmat dan manfaat Bank Syariah hanya akan terlihat jika elemen-elemen sistem yang lain juga turut ditegakkan. Tanpa itu , boleh jadi kehadiran Bank Syariah hanya akan menghasilkan kaum muslimin yang makmur yang kaya secara material namun rapuh secara akhlak dan ibadah. Bank Syariah hanya akan maju dan berkembang jika orang-orang yang terlibat didalamnya, baik pemilik modal, peminjam, dan pengelola, memiliki komitmen yang utuh kepada Islam. Karena dalam banyak hal , Bank Syariah lebih menekankan aspek kesediaan menolong tanpa pamrih, selain mengharap balasan dari Allah SWT.

Kadang banyak orang terjebak kedalam pengertian bahwa Bank Syariah sama dengan bank tanpa bunga. Padahal Bank Syariah sangat jauh dari itu. Bank Syariah memiliki ciri karakter sendiri yang berbeda dengan bank-bank konvensional. Esensi Bank Syariah tidak hanya dilihat dari ketiadaan sistem riba dalam seluruh transaksinya, tetapi didalamnya terdapat sistem yang membawa manusia mendapatkan kebahagiaan lahir dan batin. Ada beberapa karakter dan ciri utama Bank Syariah, diantaranya :

\section{Berdimensi keadilan dan pemerataan melalui sistem bagi hasil}

Dengan sistem bagi hasil, pihak pemberi modal dan peminjam menanggung bersama resiko laba maupun rugi. Hal ini membuat kekayaan tidak hanya beredar pada satu golongan. Terjadi proses penyebaran modal yang juga berarti penyebaran kesempatan berusaha. Dan ini pada akhirnya membuat pemerataan dapat terlaksana. Berbeda dengan bank konvensional, yang ada hanyalah penumpukan modal pada pemilik modal. Akan selalu tercipta jurang antara si kaya dan si miskin.

\section{Jaminan}

Bank Syariah menjadikan proyek yang sedang dikerjakan sebagai jaminan, sementara bank konvensional (dengan bunga) menjadikan kekayaan si peminjam sebagai jaminannya. Sehingga hanya orang-orang kaya dan mampu sajalah yang dapat meminjam pada bank, sementara si fakir dan lemah tidak dapat meminjam. Para konglomerat selalu ditawari kredit, sementara pengusaha lemah tidak pernah mendapat bagian.

\section{Menciptakan rasa kebersamaan}

Bank Syariah menciptakan suasana kebersamaan antara pemilik modal dengan peminjam. Keduanya berusaha untuk menghadapi risiko secara adil. Dan rasa kebersamaan ini mampu membuat seorang peminjam merasa tenang sehingga dapat mengerjakan proyeknya dengan baik.

\section{Bersifat Mandiri}

Bank Syariah bersifat mandiri dan tidak terpengaruh secara langsung oleh gejolak moneter, baik dalam negeri maupun internasional, karena kegiatan operasi bank ini tidak menggunakan perangkat bunga. Karena itu bank sistem ini tidak berdampak inflasi, mendorong investasi, mendorong pembukaan lapangan kerja baru dan pemerataan pendapatan.

\section{Persaingan Sehat}


Persaingan antara Bank Syariah tidak saling mematikan tetapi saling menghidupi. Bentuk persaingan antara Bank Syariah adalah berlomba-lomba untuk lebih tinggi dari yang lain dalam memberikan porsi bagi hasil kepada nasabah. Sehingga mereka yang mampu membina peminjam dengan baik akan berhasil. Dan kesempatan ini terbuka untuk semua Bank Syariah. Berbeda dengan bank-bank konvensional, Persaingan antara bank-bank mereka saling mematikan. Bank-bank besar dengan mudah memberikan bunga besar kepada nasabahnya. Sementara yang kecil hanya melihat dengan kesedihan. Dan kesemuanya dipertegas dengan komitmen Bank Syariah untuk mengangkat kaum dhu'afa.

Sebagai sebuah lembaga bisnis, Bank Syariah, seperti bank-bank lainnya harus memiliki daya tarik ekonomi. Namun pertimbangan ekonomi bukan merupakan pertimbangan dasar, ada hal lain yang lebih penting, yaitu moral. Karena itu produk-produk yang diberikan Bank Syariah tidak pernah lepas dari aturan syariah. Selalu ada pertimbangan yang bersifat ukhrawi, yaitu pertimbangan halal dan haram.

\section{B. Asas-Asas Perbankan Syariah}

Menurut Pasal 2 UU Nomor 21 Tahun 2008, perbankan syariah dalam melakukan kegiatan usahanya berasaskan prinsip syariah, demokrasi ekonomi, dan prinsip kehatihatian. Dalam penjelasan Pasal 2 dikemukakan kegiatan usaha yang berasaskan berikut ini:

1. Prinsip syariah, antara lain kegiatan usaha yang tidak mengandung unsur:

a. Riba, yaitu penambahan pendapatan secara tidak sah antara lain dalam transaksi pertukaran barang sejenis yang tidak sama kualitas,kuantitas, dan waktu penyerahan $(f a d h l)$, atau dalam transaksi pinjam meminjam yang mempersyaratkan nasabah penerima fasilitas mengembalikan dana yang diterima melebihi pokok pinjaman karena berjalannya waktu (nasi'ah)

b. Maisir, yaitu transaksi yang digantungkan kepada suatu keadaan yang tidak pasti dan bersifat untung-untungan.

c. Gharar, yaitu transaksi yang objeknya tidak jelas, tidak memiliki, tidak diketahui keberadaanya, atau tidak dapat diserahkan pada saat transaksi dilakukan, kecuali diatur lain dalam syariah

d. Haram, yaitu transaksi yang objeknya dilarang dalam syariah

e. Zalim, yaitu transaksi yang menimbulkan ketidakadilan bagi pihak lainnya.

2. Demokrasi ekonomi adalah kegiatan ekonomi syariah yang mengandung nilai keadilan, kebersamaan, pemerataan, dan kemanfaatan.

3. Prinsip kehati-hatian adalah pedoman pengelolaan bank yang wajib dianut guna mewujudkan perbankan yang sehat, kuat, dan efisien, sesuai dengan peraturan perundang-undangan.

\section{Sistem Operasional Bank Syariah}

Pengertian bank menurut Undang-Undang No. 10 tahun 1998 tentang perubahan atas Undang-Undang No. 7 tahun 1992 tentang perbankan adalah badan usaha yang menghimpun dana dari masyarakat dalam bentuk simpanan dan menyalurkannya kepada 
masyarakat dalam bentuk kredit dan/atau bentuk-bentuk lainnya dalam rangka meningkatkan taraf hidup rakyat banyak.

Di Indonesia, menurut jenisnya bank terdiri dari Bank Umum dan Bank Perkreditan Rakyat. Dalam Pasal 1 ayat 3 Undang-Undang No. 10 Tahun 1998 menyebutkan bahwa bank umum adalah bank yang melaksanakan kegiatan usaha secara konvensional dan/atau berdasarkan prinsip syariah yang dalam kegiatannya memberikan jasa dalam lalu lintas pembayaran.

Bank Konvensional dapat didefinisikan seperti pada pengertian bank umum pada pasal 1 ayat 3 Undang-Undang No. 10 tahun 1998 dengan menghilangkan kalimat "dan atau berdasarkan prinsip syariah", yaitu bank yang melaksanakan kegiatan usaha secara konvensional yang dalam kegiatannya memberikan jasa dalam lalu lintas pembayaran. Sedangkan Bank Syariah, adalah bank yang beroperasi dengan tidak mengandalkan pada bunga. Bank Syariah juga dapat diartikan sebagai lembaga keuangan/perbankan yang operasional dan produknya dikembangkan berlandaskan Al-Qur'an dan Hadits Nabi SAW. Antonio dan Perwataatmadja membedakan menjadi dua pengertian, yaitu Bank Syariah dan Bank yang beroperasi dengan prinsip syariah Islam. Bank Syariah adalah bank yang beroperasi dengan prinsip syariah Islam dan bank yang tata cara beroperasinya mengacu kepada ketentuan-ketentuan Al-Qur'an dan Hadits. Bank yang beroperasi sesuai dengan prinsip syariah Islam adalah bank yang dalam beroperasinya mengikuti ketentuan-ketentuan syariah Islam, khususnya yang menyangkut tata cara bermuamalah secara Islam.

Pada sistem operasi Bank Syariah, pemilik dana menanamkan uangnya di bank tidak dengan motif mendapatkan bunga, tapi dalam rangka mendapatkan keuntungan bagi hasil. Dana nasabah tersebut kemudian disalurkan kepada mereka yang membutuhkan (misalnya modal usaha), dengan perjanjian pembagian keuntungan sesuai kesepakatan. Sistem operasional tersebut meliputi :

\section{Sistem Penghimpunan Dana}

Metode penghimpunan dana yang ada pada Bank Konvensional didasari teori yang diungkapkan Keynes yang mengemukakan bahwa orang membutuhkan uang untuk tiga kegunaan, yaitu fungsi transaksi, cadangan dan investasi. Teori tersebut menyebabkan produk penghimpunan dana disesuaikan dengan tiga fungsi tersebut, yaitu berupa giro, tabungan dan deposito.

Berbeda halnya dengan Bank Konvensional, Bank Syariah tidak melakukan pendekatan tunggal dalam menyediakan produk penghimpunan dana bagi nasabahnya. Pada dasarnya, dilihat dari sumbernya, dana Bank Syariah terdiri atas:

a. Modal

Modal adalah dana yang diserahkan oleh para pemilik (owner). Dana modal dapat digunakan untuk pembelian gedung, tanah, perlengkapan, dan sebagainya yang secara tidak langsung menghasilkan (fixed asset/non earning asset). Selain itu, modal juga dapat digunakan untuk hal-hal yang produktif, yaitu disalurkan menjadi pembiayaan.

Mekanisme penyertaan modal pemegang saham dalam perbankan syariah, dapat dilakukan melalui musyârakah fi sahm asy-syarikah atau equity participation pada saham perseroan bank. 
b. Salah satu prinsip yang digunakan Bank Syariah dalam memobilisasi dana adalah dengan menggunakan prinsip titipan. Akad yang sesuai dengan prinsip ini adalah alwadî'ah.

Dalam prinsip ini, bank menerima titipan dari nasabah dan bertanggung jawab penuh atas titipan tersebut. Nasabah sebagai penitip berhak untuk mengambil setiap saat, sesuai dengan ketentuan yang berlaku.

\section{c. Investasi (Mudhârabah)}

Akad yang sesuai dengan prinsip investasi adalah mudhârabah yang mempunyai tujuan kerjasama antara pemilik dana (shâhibul mâl) dengan pengelola dana (mudhârib), dalam hal ini adalah bank. Pemilik dana sebagai deposan di Bank Syariah berperan sebagai investor murni yang menanggung aspek sharing risk dan return dari bank. Deposan, dengan demikian bukanlah lender atau kreditor bagi bank seperti halnya pada Bank Konvensional.

\section{Sistem Penyaluran Dana (Financing)}

Produk penyaluran dana di Bank Syariah dapat dikembangkan dengan tiga model, yaitu:

a. Transaksi pembiayaan yang ditujukan untuk memiliki barang dilakukan dengan prinsip jual beli. Prinsip jual beli ini dikembangkan menjadi bentuk pembiayaan pembiayaan murâbahah, salam dan istishna'.

b. Transaksi pembiayaan yang ditujukan untuk mendapatkan jasa dilakukan dengan prinsip sewa (Ijârah).

Transaksi ijârah dilandasi adanya pemindahan manfaat. Jadi pada dasarnya prinsip ijârah sama dengan prinsip jual beli, namun perbedaannya terletak pada objek transaksinya. Bila pada jual beli objek transaksinya adalah barang, maka pada ijârah objek transaksinya jasa.

c. Transaksi pembiayaan yang ditujukan untuk usaha kerjasama yang ditujukan guna mendapatkan sekaligus barang dan jasa, dengan prinsip bagi hasil. Prinsip bagi hasil untuk produk pembiayaan di Bank Syariah dioperasionalkan dengan pola-pola musyârakah dan mudhârabah (Muhammad Syafi' I Antonio, 2009:29-35).

\section{Analisis Perbedaan Bank Syariah dengan Bank Konvensional}

Bank Konvensional dan Bank Syariah dalam beberapa hal memiliki persamaan, terutama dalam sisi teknis penerimaan uang, mekanisme transfer, teknologi komputer yang digunakan, persyaratan umum pembiayaan, dan lain sebagainya. Perbedaan antara Bank Konvensional dan Bank Syariah menyangkut aspek legal, struktur organisasi, usaha yang dibiayai, dan lingkungan kerja.

\section{Akad dan Aspek Legal}

Akad yang dilakukan dalam Bank Syariah memiliki konsekuensi duniawi dan ukhrawi karena akad yang dilakukan berdasarkan hukum Islam. Nasabah seringkali berani melanggar kesepakatan/perjanjian yang telah dilakukan bila hukum itu hanya berdasarkan hukum positif belaka, tapi tidak demikian bila perjanjian tersebut memiliki pertanggungjawaban hingga yaumil qiyamah nanti (Afzalur Rahman, 2009:34). Setiap akad dalam perbankan syariah, baik dalam hal barang, pelaku transaksi, maupun ketentuan lainnya harus memenuhi ketentuan akad 


\section{Struktur Organisasi}

Bank Syariah dapat memiliki struktur yang sama dengan Bank Konvensional, misalnya dalam hal komisaris dan direksi, tetapi unsur yang amat membedakan antara Bank Syariah dan Bank Konvensional adalah keharusan adanya Dewan Pengawas Syariah yang berfungsi mengawasi operasional bank dan produk-produknya agar tidak bertentangan dengan syariah (Bank Indonesia, 1999:20).

Dewan Pengawas Syariah biasanya diletakkan pada posisi setingkat Dewan Komisaris pada setiap bank. Hal ini untuk menjamin efektivitas dari setiap opini yang diberikan oleh Dewan Pengawas Syariah. Karena itu biasanya penetapan anggota Dewan Pengawas Syariah dilakukan oleh Rapat Umum Pemegang Saham, setelah para anggota Dewan Pengawas Syariah itu mendapat rekomendasi dari Dewan Syariah Nasional (AAOIFI,1999: 19). Adapun struktur organisasi Bank Syariah dapat dilihat pada gambar sebagai berikut:

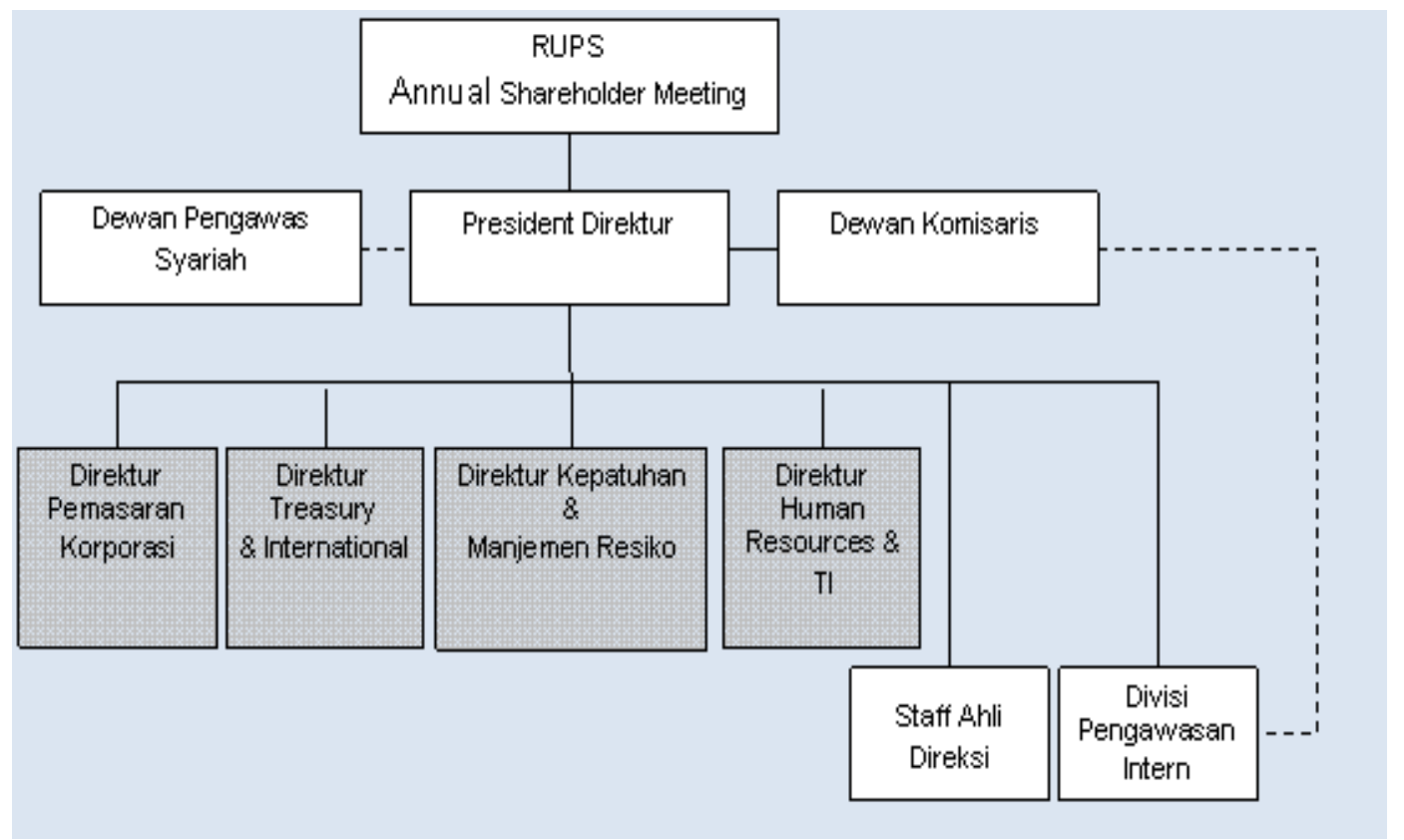

Gambar 1. Struktur Organisasi Bank Syariah

\section{Bisnis dan Usaha yang Dibiayai}

Bisnis dan usaha yang dilaksanakan Bank Syariah, tidak terlepas dari kriteria syariah. Hal tersebut menyebabkan Bank Syariah tidak akan mungkin membiayai usaha yang mengandung unsur-unsur yang diharamkan. Terdapat sejumlah batasan dalam hal pembiayaan. Tidak semua proyek atau objek pembiayaan dapat didanai melalui dana Bank Syariah, namun harus sesuai dengan kaidah-kaidah syariah.

\section{Lingkungan dan Budaya Kerja}

Sebuah Bank Syariah selayaknya memiliki lingkungan kerja yang sejalan dengan syariah. Dalam hal etika, misalnya sifat amânah dan shiddiq, harus melandasi setiap karyawan sehingga tercermin integritas eksekutif muslim yang baik, selain itu karyawan Bank Syariah harus profesional (fathanah), dan mampu melakukan tugas secara team- 
work dimana informasi merata diseluruh fungsional organisasi (tabligh). Dalam hal reward dan punishment, diperlukan prinsip keadilan yang sesuai dengan syariah.

Selain hal diatas, terdapat pula beberapa hal mengenai perbedaan antara Bank Syariah dengan Bank Konvensional, sebagai berikut:

\section{Perbedaan Falsafah}

Perbedaan pokok antara Bank Konvensional dengan Bank Syariah terletak pada landasan falsafah yang dianutnya. Bank Syariah tidak melaksanakan sistem bunga dalam seluruh aktivitasnya sedangkan bank konvensional justru kebalikannya. Hal inilah yang menjadi perbedaan yang sangat mendalam terhadap produk-produk yang dikembangkan oleh Bank Syariah, dimana untuk menghindari sistem bunga maka sistem yang dikembangkan adalah jual beli serta kemitraan yang dilaksanakan dalam bentuk bagi hasil. Dengan demikian sebenarnya semua jenis transaksi perniagaan melalui Bank Syariah diperbolehkan asalkan tidak mengandung unsur bunga (riba). Riba secara sederhana berarti sistem bunga berbunga yang dalam semua prosesnya bisa mengakibatkan membengkaknya kewajiban salah satu pihak. Riba, sangat berpotensi untuk mengakibatkan keuntungan besar di suatu pihak namun kerugian besar di pihak lain, atau malah ke dua-duanya.

\section{Kewajiban Mengelola Zakat, Infak dan Sedekah}

Bank Syariah diwajibkan menjadi pengelola zakat yaitu dalam arti wajib membayar zakat, menghimpun, dan mendistribusikannya. Hal ini merupakan fungsi dan peran yang melekat pada Bank Syariah untuk penggunaan dana-dana sosial (zakat, infak, sedekah). Sebagaimana yang tercantum dalam UU No.21 Tahun 2008 Pasal 4 Ayat (2) : Bank Syariah dan UUS dapat menjalankan fungsi sosial dalam bentuk lembaga baitul mal, yaitu menerima dana yang berasal dari zakat, infak, sedekah, hibah, atau dana sosial lainnya dan menyalurkannya kepada organisasi pengelola zakat.

\section{Produk}

Bank Syariah tidak memberikan pinjaman dalam bentuk uang tunai, tetapi bekerja sama atas dasar kemitraan, seperti prinsip bagi hasil (mudhârabah ), prinsip penyertaan modal (musyârakah), prinsip jual beli (murâbahah), dan prinsip sewa (ijarah). Sedangkan pada Bank Konvensional terdapat deposito, pinjaman uang tunai berbunga.

\section{Tujuan dan Fungsi}

Sistem Perbankan Syariah, seperti halnya aspek-aspek lain dari pandangan hidup islam, merupakan sarana pendukung untuk mewujudkan tujuan dari sistem sosial dan ekonomi islam. Beberapa tujuan dan fungsi penting yang dari sistem Perbankan Syariah adalah:

a. Kemakmuran ekonomi yang meluas dengan tingkat kerja yang penuh dan tingkat pertumbuhan ekonomi yang optimum (economic well-being with full employment and optimum rate of economic growth).

b. Keadilan sosial-ekonomi, distribusi pendapatan dan kekayaan yang merata (socioeconomic justice and equitable distribution of income and wealth).

c. Stabilitas nilai uang untuk memungkinkan alat tukar tersebut menjadi suatu unit perhitungan yang terpercaya, standar pembayaran yang adil dan nilai simpanan yang stabil (stability in the value of money). 
d. Mobilisasi dan investasi tabungan bagi pembangunan ekonomi dengan cara cara tertentu yang menjamin bahwa pihak-pihak yang berkepentingan mendapatkan bagian pengembalian yang adil (mobilisation of savings).

e. Pelayanan efektif atas semua jasa-jasa yang biasanya diharapkan dari sistem perbankan (effective other services) (Capra, Umer M, 2000:89).

Mungkin ada sebagian pihak yang mengatakan bahwa tujuan dan fungsi dari sistem keuangan dan Perbankan Syariah seperti yang diungkapkan di atas adalah sama dengan yang ada dalam kapitalisme. Walaupun nampak ada kesamaan, dalam kenyataannya terdapat perbedaan yang penting dalam hal penekanan, yang muncul dari perbedaan dua sistem tersebut dalam komitmennya terhadap nilai-nilai spiritual, keadilan sosialekonomi serta dalam persaudaraan sesama manusia.

Tujuan-tujuan dalam islam adalah suatu bagian tak terpisahkan dari ideologi dan kepercayaan islam. Hal tersebut merupakan suatu input penting sebagai bagian dari suatu output tertentu. Tujuan-tujuan tersebut membawa kesucian dan dalam hal yang didasarkan pada Al-Qur'an dan As-Sunnah, tujuan tujuan tersebut bukanlah semata-mata sebagai alat tawar politik dan kebijaksanaan.

Akan tetapi, strategi yang sangat penting bagi terwujudnya suatu tujuan yang merupakan suatu keunikan yang dapat disumbangkan oleh islam. Sistem Perbankan Syariah ditegakkan atas kemutlakan larangan dari pembayaran atau penerimaan setiap yang ditentukan (predetermined) atas pinjaman atau kredit. Dengan demikian konsep bunga (interest) atas hutang secara tegas dilarang. Sistem Perbankan Syariah lebih condong pada upaya untuk mendorong penerapan sharing risiko, mempromosikan kewirausahaan(entrepreneurship), melemahkan perilaku spekulatif, dan menekankan kesucian akad. Saluran permodalan yang mungkin bisa digunakan untuk masyarakat islam dalam membuka usaha adalah perusahaan perorangan (sole proprietorship), perusahaan patungan (partnership) (termasuk mudhârabah dan syirkah) dan perusahaan perseroaan (joint stock company).

\section{SIMPULAN}

Bank Syariah berfungsi sebagai sarana untuk mengumpulkan tabungan masyarakat dan mengembangkannya. Intinya bahwa Bank Syariah adalah lembaga yang berfungsi untuk menginvestasikan dana masyarakat sesuai dengan anjuran Islam dengan efektif, produktif dan untuk kepentingan umat Islam. Tujuan utama dari Bank Syariah, yaitu menyatukan umat Islam, mengembalikan kekuatan, peran, dan kedudukan Islam di muka bumi ini bisa tercapai.

Bank Konvensional didirikan untuk mendapatkan keuntungan material sebesar-besarnya, sedangkan Bank Syariah didirikan untuk memberikan kesejahteraan material dan spiritual.Kesejahteraan material dan spiritual tersebut didapat melalui usaha pengumpulan dan penyaluran dana yang halal. Artinya, Bank Syariah tidak akan menyalurkan dana untuk usaha pabrik minuman keras atau usaha lain yang tidak bisa dijamin bahwa hasilnya berasal dari kegiatan yang halal. Karena itu dapat dikatakan bahwa konsep keuntungan pada Bank Konvensional lebih cenderung, berfokus pada sudut keuntungan materi, sedangkan konsep keuntungan pada Bank Syariah harus memperhatikan keuntungan dari sudut duniawi dan ukhrawi(akhirat).Jika memang tujuan nasabah sesuai dengan tujuan Bank Syariah, maka secara prinsip tidak ada kekurangan 
dari menabung di Bank Syariah karena adanya keseimbangan antara duniawi dan ukhrawi. Namun apabila tujuan nasabah lebih ke aspek-aspek material, maka bisa jadi keuntungan yang diperoleh akan kurang sesuai dengan harapan.

\section{DAFTAR PUSTAKA}

AAOIFI, 1999. Accounting and Auditing and Governance Standards for Islamic Financial Institution. Bahrain: Manama,

Afzalur Rahman, 2009. Economic Doctrines of Islam. Lahore: Islamic Publication.

Bank Indonesia, Petunjuk pelaksanaan Pembukuan Kantor Bank Syariah ( Jakarta: Bank Indonesia, 1999).

Capra, Umer M. 2000, Sistem Moneter Islam. Edisi terjemahan. Jakarta: Gema Insani Press \& Tazkia Cendekia.

Muhammad, 2005. Manajemen Bank Syariah, Yogyakarta: UPP AMP YKPN.

Muhammad Syafi'I Antonio, 2009. Bank Syariah Dari Teori Ke Praktik. Jakarta: Gema Insani.

Peraturan Pemerintah No. 72 Tahun 1992 tentang Bank Berdasarkan Prinsip Bagi Hasil.

Undang-Undang No.7 Tahun 1992 tentang Perbankan.

Undang-Undang No. 10 Tahun 1998 tentang perubahan UU No. 7 Tahun 1992 tentang perbankan

Undang-Undang No.21 Tahun 2008 tentang Perbankan Syariah. 